\title{
Penentuan Segmentasi dan Target Pasar Pada Home Care di Klinik Utama Mutiara Cikutra Bandung
}

\author{
Lucy Nurfadilah dan Ine Aprianti \\ Universitas Sangga Buana YPKP, Indonesia
}

Email corresponding author: Lucy.nurfadilah@usbypkp.ac.id/ine.aprianti@usbypkp.ac.id

\begin{abstract}
ABSTRAK
Bentuk bisnis homecare pada masa kini merupakan bisnis yang mulai banyak dilirik oleh pada bidang kesehatan dikarena faktor pandemi yang sedang terjadi saat ini. Banyaknya peluang dari bisnis homecare maka dibuat sedemikian rupa agar dapat bersaing dengan pesaing di bidangnya. Dahulu setiap pasien atau costumer bila memerlukan jasa diharuskan pergi langsung ke tempat Klinik kesehatan ataupun rumah sakit. Tetapi kini dapat dilakukan melalui Home Care (HC). Selain dapat memudahkan para konsumen HC pun penjadi alternative untuk Klinik atau Rumah Sakit yang memiliki keterbatasan fasilitas dan ruangan dalam menangani dan melayani pasien. Semakin meluasnya target pasar HC maka terlihat semakin berpeluangnya bisnis tersebut pada masa yang akan dating. Metode yang digunakan dalam penelitian ini adalah bersifat deskriptif analitik dengan menggunakan pendekatan kualitatif dan kuantitatif. Teknik pengumpulan data dengan menggunakan data primer dan sekunder. Data primer dengan menggunakan data berdasarkan Interview langsung dari informan klinik serta menggunakan 150 responden yang merupakan random sampling costumer yang pernah menggunakan layanan HC pada klinik tersebut.
\end{abstract}

Kata Kunci: Segmentasi, Target, Pasar, Target Pasar

\section{ABSTRACT}

The form of the homecare business today is a business that is starting to get a lot of attention in the health sector due to the current pandemic. The number of opportunities from the homecare business is made in such a way that it can compete with competitors in its field. In the past, every patient or customer when they needed services was required to go directly to the health clinic or hospital. But now it can be done through Home Care (HC). Besides being able to make it easier for HC consumers, it is also an alternative for clinics or hospitals that have limited facilities and space in handling and serving patients. The wider the target market for HC, the more likely the business will be in the future. The method used in this research is descriptive analytic by using qualitative and quantitative approaches. Data collection techniques using primary and secondary data. Primary data using data based on interviews directly from clinic informants and using 150 respondents who are random sampling customers who have used HC services at the clinic.

Keywords: Segmentation, Target, Market, Target Market

\section{PENDAHULUAN}

Persaingan dalam dunia bisnis tentu merupakan hal yang tidak asing lagi, bahkan dari setiap jenis usaha termasuk dalam bidang jasa kesehatan. Dari setiap rumah sakit serta klinik kesehatan berlomba-lomba agar menarik perhatian para pasien ataupuncostumernya. 
Banyaknya peluang dari bisnis tersebut maka dibuat sedemikian rupa agar bersaing dengan pesaing di bidangnya. Dahulu setiap pasien atau costumer bila memerlukan jasa diharuskan pergi langsung ke tempat Klinik kesehatan ataupun rumah sakit. Tetapi kini dapat dilakukan melalui Home Care (HC). Selain dapat memudahkan para konsumen HC pun penjadi alternative untuk Klinik atau Rumah Sakit yang memiliki keterbatasan fasilitas dan ruangan dalam menangani dan melayani pasien.

Berawal dari keterbatasan tersebutlah maka berubah menjadi peluang bisnis khususnya yang terjadi pada Klinik Mutiara Cikutra Bandung (KMC) yang bertempat di Jalan Cikutra Bandung. Klinik ini memiliki layanan HC cukup lengkap meliputi dari kebutuhahan ibu hamil, perawatan pijat bayi,spa bayi, konsultasi laktasi hingga perawatan luka bekas cessar. Terapis bisa melayani konsumen dengan baik dan teliti dengan cukup booking 1 hari sebelum. Selain dari layanan diatas ada beberapa kasus yang bisa menggunakan HC untuk kasus-kasus keadaan tertentu yang membutuhkan perawatan dalam waktu yang lama sehingga pasien lebih nyaman untuk dirawat dirumah dan terapis atau perawat datang langsung kerumah secara berkala untuk memeriksa keadaan pasien tersebut.

Namun sekarang ini masa rawat inap bisa dikelola menjadi semakin pendek karena selain akan mengurangi beban pasien, juga akan meningkatkan efisiensi kepada RS dan klinik. Penelitian Lewin (1991) yang dikutip dari Suharyati (1998), menyimpulkan bahwa:

"Using home care in combination with in-patient treatment is less costly in all cases than simply using inpatient treatment. When the cost benefit analysis includes a quality of life factor, combination inpa-tient/home therapy has even greater saving".

Permasalahan yang terjadi adalah tidak siapnya keluarga untuk merawat pasien karena ketidaktahuan, ketidakmampuan atau ketidakmauan mereka untuk merawat pasien di rumah setelah pulang dari rumah sakit.

Menyikapi kondisi ini maka perawatan pasien di rumah dengan bantuan perawat atau tenaga kesehatan lain menjadi alternatif yang terbaik. Seperti yang diutarakan Achmad Sujudi sewaktu masih menjabat sebagai Menkes, bahwa para pasien yang terpaksa harus tinggal di rumah karena lemah atau pasca perawatan dan membutuhkan perawatan kesehatan dapat dibantu dengan yang biasa dikenal dengan Home Care (HC) (www.depkes.go.id). Hal senada juga disampaikan oleh Mamat Lukman (2014), bahwa RS tidak saja memberikan pelayanan yang bersifat kuratif namun juga bisa memberikan pelayanan yang komprehensif (promotif, preventif, dan rehabilitatif) kepada pasien yaitu dengan program Hospital Home Care (HHC). Ditambahkannya pula bahwa melalui upaya ini klinik akan memaksimalkan bentuk pelayanan sampai ke tingkat perifer yaitu rumah pasien.

Trisnantoro (2015) juga menyetujui adanya HC yang diselenggarakan oleh RS atau klinik seperti yang diutarakannya, “....Sebenarnya sangat menyenangkan jikaklinik mempunyai bagian yang mengurusi pasien-pasien yang harus mendapat home care. Dengan adanya kelompok kerja ini maka keluarga pasien berhubungan dengan manajer klinik dan mempersiapkan paket perawatan di rumah secara menyeluruh. Hal ini dapat menghemat pengeluaran, dan keluarga pasien tidak terlalu berat menyiapkan segala sesuatunya”.

Semakin jelas kiranya bahwa perawatan yang berbasis rumah merupakan alternatif terbaik yang dapat dikembangkan untuk merawat pasien yang memerlukan perawatan lama karena terbukti banyak memberikan manfaat baik bagi pasien maupun klinik. Beberapa rumah sakit di Bandung dan Jakarta ada yang sudah menyediakan pelayanan HC secara resmi dan ada diantaranya yang proaktif dalam mengenalkan HC ini pada masyarakat baik melalui penyediaan leaflet $\mathrm{HC}$ di klinik maupun pembuatan situs HC di internet. Harga untuk HC tentu bervariasi oleh karena itu banyak strategi yang digunakan klinik agar menarik minat para konsumen menggunakan layanan jasa $\mathrm{HC}$, namun stigma masyarakat akan $\mathrm{HC}$ masih beragam mulai dari ada yang menganggap praktis walaupun relatif sedikit mahal tapi praktis ataupun 
ada yang menganggap HC merupakan layanan private yang eksklusif dan tidak ramah dikantong, maka dari itu tugas bagian pemasaran klinik adalah untuk mengklasifikasian segmentasi untuk mengoptimalkan target pasar agar dapat menginformasikan layanan dan harga dengan baik guna membidik secara tepat target pasar tersebut. Diketahui bahwa jumlah pengguna layanan $\mathrm{HC}$ mengalami fluktuatif yang signifikan sebagai berikut :

Tabel 1. Data Pengguna Layanan Hc Kmc

\begin{tabular}{|l|c|c|c|c|c|c|}
\hline & Januari 2020 & Februari 2020 & Maret 2020 & April 2020 & Mei 2020 \\
\hline P. Laktasi & 86 & 130 & 143 & 71 & 76 \\
\hline P. Bayi \& Spa & 142 & 124 & 61 & 23 & 90 \\
\hline P. Ibu Hamil & 87 & 76 & 54 & 47 & 77 \\
\hline HC Cessar & 18 & 21 & 7 & 12 & 19 \\
\hline HC Khusus & 7 & 6 & 13 & 3 & 2 \\
\hline
\end{tabular}

Data diolah oleh peneliti

Dari hasil diatas maka peneliti melihat potensi yang dimiliki oleh klinik tersebut juga dikenali dan penentuan pasar yang tepat agar para pelanggan tetap setia menggunakan layanan HC serta menarik minat pelanggan baru.

\section{KAJIAN PUSTAKA}

\section{Segmentasi}

Kotler (2003:173) mengatakan bahwa segmentasi pasar merupakan suatu aktivitas pasar membagi atau mengelompokkan pasar yang heterogen menjai pasar yang homogen memiliki kesamaan dalam hal minat, daya beli, geografis, perilaku pembelian, maupun gaya hidup. Sedangkan menurut Kasali (2005:119) segmentasi pasar adalah proses mengkotak- kotakkan pasar (yang heterogen) kedalam kelompok-kelompok "Potential Customers" yang memiliki kesamaan kebutuhan atau kesamaan karakter yang memiliki respon yang sama dalam membelanjakan uangnya. Tidak ada cara tunggal untuk membuat segmen pasar. Seorang pemasar harus mencoba variabel segmentasi yang berbeda, sendiri atau dalam kombinasi, mencari cara terbaik untuk memandang struktur pasar.

\section{Target Pasar}

Setelah segmen pasar dievaluasi, langkah selanjutnya yaitu memilih segmen yang akan dijadikan target atau pasar sasaran. Dalam memilih pasar sasaran yang optimal, perlu diperhatikan beberapa kriteria berikut:

\section{Responsif}

Pasar sasaran harus responsif terhadap produk atau program-program pemasaran yang dikembangkan. Langkah ini harus dimulai dengan studi segmentasi yang jelas karena tanpa pasar sasaran yang jelas produsensasaran harus responsif terhadap produk atau program-program pemasaran yang dikembangkan. Langkah ini harus dimulai dengan studi segmentasi yang jelas karena tanpa pasar sasaran yang jelas produsen menanggung resiko yang terlalu besar.

2. Potensi penjualan

Potensi penjualan harus cukup luas. Semakin besar pasar sasaran, semakin besar nilainya. Besarnya bukan hanya ditentukan oleh jumlah populasi tapi juga daya beli dan keinginan pasar untuk memiliki produk tersebut.

3. Pertumbuhan yang memadai

Pasar tidak dapat dengan segera bereaksi. Pasar tumbuh perlahan-lahan sampai akhirnya meluncur dengan cepat dan mencapai titik pendewasaan.

4. Jangkauan media 
Pasar sasaran dapat dicapai dengan optimal kalau pemasar tepat memilih media untuk mempromosikan dan memperkenalkan produknya.

Setelah proses segmentasi pasar dilakukan, langkah selanjutnya adalah pelaksanaan target pasar. Untuk melakukannya, diperlukan proses yang urut dan sistematis, yakni sebagai berikut:

1. Mengembangkan acuan pemasaran untuk menentukan segmen pasar yang telah ditarget.

2. Memilih segmen pasar serta target perusahaan.

3. Mengembangkan produk yang sesuai segmen pasar.

4. Mengembangkan profil segmen pasar yang akan dihasilkan.

5. Menambah kriteria segmen pasar apabila diperlukan.

6. Melakukan identifikasi segmentasi pasar yang sudah ada.

Banyak organisasi yang memanfaatkan pemasaran sasaran yaitu dengan membedakan segmen-segmen pasar utama, membidik satu atau dua segmen itu, dan mengembangkan produk serta program pemasaran yang dirancang khusus bagi masing-masing segmen. Pemasaran sasaran dilakukan dengan tiga langkah utama seperti yang ditunjukkan dalam gambar 2.1.

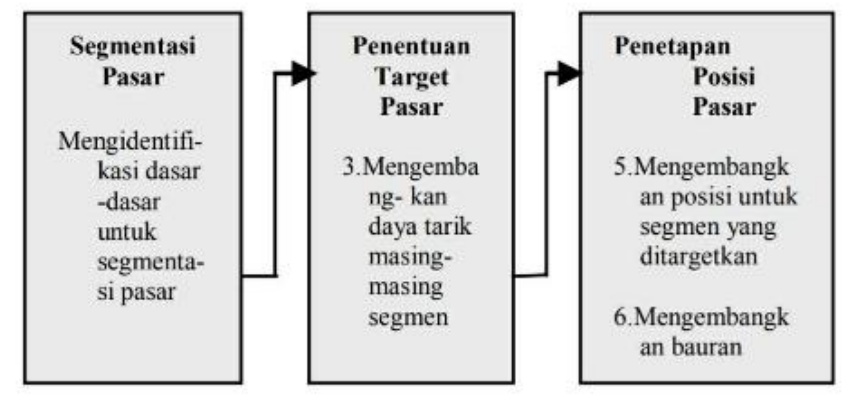

Gambar 2.1.

Segmentasi, Penentuan Target, dan Penetapan Posisi Pasar

Sumber: Kotler , P. \& Armstrong, G., Princi-ples of Marketing, Eleventh Edition, Pearson

Prentice Hall International, Inc. New Jersey, p.183, 2006

\section{METODE PENELITIAN}

Penelitian ini bersifat deskriptif analitik dengan menggunakan pendekatan kualitatif dan kuantitatif. Teknik pengumpulan data dengan menggunakan data primer dan sekunder. Data primer dengan menggunakan data berdasarkan Interview langsung dari informan klinik bersangkutan berdasakan kriteria kesesuaian serta kecukupan dan data sekunder menggunakan telaah analisis dokumen dari klinik dan dinkes serta menyebarkan kuesioner kepada 150 responden yang merupakan random sampling costumer yang pernah menggunakan layanan HC pada klinik tersebut. 


\section{HASIL DAN PEMBAHASAN}

\section{Analisis Segmen Pelanggan Klinik Mutiara Cikutra (KMC) Berdasarkan Faktor Demografi : dilihat dari Umur, Jenis Kelamin, Pekerjaan, Penghasilan, Agama dan Penyakit yang Diderita}

Sebagian besar pelanggan dari KMC dilihat dari umur kisaran 20 - 40 tahun, dimana umur tersebut merupakan umur produktif untuk hamil dan melahirkan karena KMC memiliki jenis HC yang banyak ditawarkan untuk perawatan ibu hamil, menyusui dan bayi. Jenis kelamin yang berlangganan pada HC 90\% wanita, 10\%nya laki-laki yang mana dengan beberapa kasus penyakit tertentu. Pekerjaan untuk pelanggan relatif bervariasi mulai dari ibu rumah tangga (36.7\%),wiraswasta(17.3\%), wanita berkarir di perusahan swasta maupun pegawai negeri sipil (46\%) dengan penghasilan $\mathrm{Rp} 2.000 .000$ - Rp. 8.000.000 ataupun diatas dari Rp. 8.000.000 dari jumlah penghasilan diatas maka peneliti mengklasifikasikan segmen menjadi 3 katagori kelas sosial yaitu Bagi yang berpenghasilan $<2$ juta dikategorikan sebagai kelas bawah, $>2,2$ - 5 juta sebagai kelas menengah, dan $>5$ juta merupakan kelas atas. Segmentasi pelanggan HC KMC berdasarkan penghasilan menghasilkan sebagian besar $(42,5 \%)$ berpenghasilan dikelas menengah, $(36,6 \%)$ berpenghasilan di kelas atas dan terakhir $(20,9 \%)$ berpenghasilan dikelas bawah. Dengan demikian bahwa dapat diketahui kelas potensial untuk HC di KMC berada di kelas menengah yang penghasilannya 2,2 - 5 juta rupiah. Kemudian untuk hasil dari berdasarkan Agama mayoritas yang menggunakan layanan $\mathrm{HC}$ di KMC adalah beragama islam yakni $87 \%$ dan sisanya $13 \%$ beragama Kristiani dan Budha. Penyakit yang diderita umumnya termasuk penyakit ringan yang bisa di rawat dirumah hanya butuh bantuan terapis untuk merawatnya kebanyakan terapis di minta untuk memijat mulai dari pijat rutin bayi, pijat Ibu hamil dan menyusui sampai pijat terapi menambah nafsu makan pada bayi dan anak.

\section{Berdasarakan faktor Geografi}

Pelanggan HC di KMC tergolong sangat melihat fleksibelitas dikarenakan beberapa walau ada yang berjarak dekat dengan klinik namun tetap menggunakan layanan HC dikarenakan alasan privasi serta mengingat keadaan yang terjadi saat ini yaitu sedang terjadi pandemi, karena yang biasanya menggunakan jasa $\mathrm{HC}$ di $\mathrm{KMC}$ adalah umur rawan serta keadaan yang rentan misalkan bayi, anak serta ibu hamil sehingga mereka lebih mau menggunakan layanan ini. Geografi untuk pelanggan HC banyak tersebar di kawasan kecamatan-kecamatan dikota bandung namun menurut data terbesar berada di Kecamatan Cibeunying Kidul yaitu 33\% dan sisanya $67 \%$ tersebar di kecamatan lain. Untuk biayanya tersendiri ada biaya transportasi berdasarkan jarak dari klinik ke tempat pasien.

\section{Berdasarakan faktor Psikologi}

Pada faktor Psikologi ini terdiri dari jenis perawatan yang diambil oleh pelanggan yakni perawatan menyeluruh (paket) atau perawatan perkedatangan terapis. Keadaan ini didasari dari kebutuhan para pelanggan HC baik itu yang menggunakan Paket ataupun bukan paket. Contohnya untuk perawatan bekas luka operasi Cessar mulai dari pembersihan luka dan penggantian perban dilakukan oleh perawat yang dapat datang langsung ke rumah pasien. Selain dari pada itu paket lain yang ditawarkan adalah untuk merawat bayi baru lahir seperti memandikannya dan perawatan intensif lainnya.

\section{Berdasarakan Faktor Prilaku}

Faktor prilaku pada responden $\mathrm{HC}$ sangatlah variatif mulai dari ketidak tahuan cara mengurus dan merawat bayi atau pasien sengga lebih memilih untuk memakai jasa professional agar tepat. Dari hasil kuesioner, kebanyakan responden adalah dibawah umur 35 tahun dimana 
responden merupakan ibu muda ataupun wanita dengan tinggat fleksibelitas tinggi dan mementingkan privasinya agar tetap terjaga terlebih lagi rasa nyaman saat melakukan HC karena dapat dengan langsung mempraktekannya sendiri dengan fasilitas yang tersedia dirumah, karena seca tidak langsung yang merawat dirumah menjadi mengetahui penanganan yang tepat dan baik karena ilmu serta pengetahuan yang jelaskan oleh terapis dan perawat saat menangani.

\section{Target Pasar Home Care}

Setelah mengevaluasi segmen-segmen yang ada, tahap selanjutnya adalah menentukan target pasar. Evaluasi terhadap segmen-segmen yang ada dengan memperhatikan ukuran dan pertumbuhan segmen, daya tarik segmen, serta sasaran dan sumber daya yang dimiliki perusahaan (Setiadi, 2003). Penentuan target pasar dimulai dengan menganalisis segmen yang paling sesuai dan memenuhi kriteria segmentasi pasar yang efektif yaitu: harus dapat diukur (measurable), jumlahnya cukup besar (subtantial), dapat dijangkau (accesible), dapat dibedakan (differentiable), dan dapat dilaksanakan (actionable). Potensi penentuan target pasar yang bertambah dikarenakan banyak hal diantarnya yaitu untuk menghindari kerumunan dan pergi ke fasilitas umum khusunya klinik kesehatan dan rumah sakit karena target pasar HC relatif rentan terpapar virus Covid-19 yang sedang merebak. Maka pilihan HC dapat menjadi alternatifyang pas untuk meminimalisir ke khawatiran para pelanggan setia, terlebih klinik tersebut melakukan tes kesehatan rutin kepada setiap terapisnya dan meyakinkan bahwa terapis yang diberi tugas untuk HC dalam keadaan sehat dan bebas dari Virus Covid-19. Dengan demikian potensi pasar sangatlah besar untuk dapat di optimalisasi penjualannya.

\section{KESIMPULAN DAN SARAN}

Berdasarkan hasil penelitian dan pembahasan yang telah dijabarkan pada bab sebelumnya mengenai Segmentasi dan Target PasarPelanggan Home Care Di Klinik Utama Mutiara Cikutra Bandung maka dapat diambil kesimpulan sebagai berikut : Hasil analisis segmen pelanggan homecare berdasarkan faktor demografi :Sebagian besar pelanggan dari KMC dilihat dari umur kisaran 20 - 40 tahun, dimana umur tersebut merupakan umur produktif untuk hamil dan melahirkan. Jenis kelamin yang berlangganan pada HC $90 \%$ wanita, Pekerjaan untuk pelanggan relative di dominasi oleh profesi pegawai negeri sipil (46\%) dengan penghasilan $\mathrm{Rp}$ 2.000.000 - Rp. 8.000.000.Segmentasi pelanggan HC KMC berdasarkan penghasilan menghasilkan sebagian besar $(42,5 \%)$ berpenghasilan dikelas menengah, Dengan demikian bahwa dapat diketahui kelas potensial untuk HC di KMC berada di kelas menengah yang penghasilannya 2,2 - 5 juta rupiah. Berdasarakan faktor GeografiPelanggan HC di KMC tergolong sangat melihat fleksibelitas dikarenakan beberapa walau ada yang berjarak dekat dengan klinik namun tetap menggunakan layanan $\mathrm{HC}$ dikarenakan alasan privasi serta mengingat keadaan yang terjadi saat ini yaitu sedang terjadi pandemi.

Berdasarakan faktor Psikologi, Pada faktor Psikologi ini terdiri dari jenis perawatan yang diambil oleh pelanggan yakni perawatan menyeluruh (paket) atau perawatanperkedatangan terapis. Keadaan ini didasari dari kebutuhan para pelanggan $\mathrm{HC}$ baik itu yangmenggunakan Paket ataupun bukan paket. Berdasarkan Faktor Prilakupada responden HC sangatlah variatif mulai dari ketidak tahuan cara mengurus dan merawat bayi atau pasien sengga lebih memilih untuk memakai jasa professional agar tepat. Dari hasil kuesioner, kebanyakan responden adalah dibawah umur 35 tahun dimana responden merupakan ibu muda ataupun wanita dengan tinggat fleksibelitas tinggi dan mementingkan privasinya agar tetap terjaga terlebih lagi rasa nyaman saat melakukan HC karena dapat dengan langsung mempraktekannya sendiri dengan fasilitas yang tersedia dirumah. 
Berdasarkan hasil tersebut, maka disarankan bagian Pemasaran Klinik Mutiara Cikutra Bandung lebih mengembangkan lagi program fokus terhadap segmentasi pasar yang menjadi target. Gambaran segmen pasar Home Care Klinik Cikutra yang didapat dari penelitian ini sebaiknya dievaluasi secara berkala dan ditindaklanjuti. terlebih di era digital dimana media sosial bisa turut membantu dalam hal memasarkan produk Home Careagar adanya peningkatan volume penjualan secara continue

\section{DAFTAR PUSTAKA}

Cravens, David W., Startegic Marketing; Alih Bahasa: Lina Salim: Edisi ke empat, Erlangga Depkes RI, Pedoman Pelayanan Keperawatan Mandiri diRumah, Pusat Pendayagunaan Tenaga Kesehatan Depkes RI, Jakarta, 2005

Kasali ,Rhenald, Membidik Pasar Indonesia; Segmenting, Targeting, Penetapan posisi, PT. Gramedia Pustaka Utama, Jakarta, 1999

Kotler, P., \& Armstrong, G., Principles of Marketing, Eleventh Edition, Pren-tice Hall International Inc., New Jer-sey , 2006

Lamb, Hair, McDaniel, Marketing, Alih ba hasa: David Octarevia, Penerbit Salemba Empat, Jakarta, 2001

Lupiyoadi, R., Manajemen Pemasaran Jasa, Penerbit Salemba Empat, Jakarta, 2004

Suharyati, Analisis Peluang Pasar Program "Hospital Home Care” di RumahSakit Umum Pusat Dokter Hasan Sadikin Bandung Tahun 1998, Tesis, Program Studi Ilmu Kesehatan Masyarakat,Program Pasca Sarjana Universitas Indonesia, 1998

SUSANTI, Ike; SYAIROZI, Muhamad Imam; LUKMAN, Hefrin Yunifa Winda. Analisis Sistem Manajemen Dalam Pengelolaan Bumdes Di Desa Bluluk. Jurnal Sains Sosio Humaniora, 2021, 5.2: 701-710.

Sucherly, Strategi Pemasaran model untuk Memelihara dan meningkatkan Kinerja Perusahaan, Unpad, Bandung, 2004

Syairozi, M. I. (2021). No Title. In KEWIRAUSAHAAN POLA PIKIR, PENGETAHUAN DAN KETERAMPILAN (pertama). https://repository.penerbitwidina.com/publications/344641/kewirausahaan-pola- 